\title{
Lembaran Sejarah \\ Paradigma Maritim dalam Membangun Indonesia: Belajar dari Sejarah
}

\section{SINGGIH TRI SULISTIYONO}

Universitas Diponegoro Semarang

\begin{abstract}
This article discusses the importance of the maritime paradigm in Indonesian national development. The maritime paradigm or what was once called as the maritime concept (wawasan bahari) or archipelagic concept (wawasan nusantara) is a development concept based on Indonesian identity as a maritime nation. The reinterpretation of this maritime paradigm is important in the context of the present period. First, to develop a clear conceptual and legal basis to the idea of the maritime state. Second, to implement in a practical manner the idea of the maritime state in the economic, political, social and cultural developments. By revitalizing and reinterpreting the maritime paradigm that is in line with the national identity it is hoped that national development based on the maritime state framework could achieve an optimal result.
\end{abstract}

\footnotetext{
Abstrak

Artikel ini membahas mengenai pentingnya paradigma maritim dalam pembangunan nasional Indonesia. Paradigma maritim atau yang pernah disebut sebagai wawasan bahari atau wawasan nusantara merupakan konsep pembangunan yang didasari dari jatidiri bangsa Indonesia sebagai bangsa maritim. Reinterpretasi terhadap paradigma maritim ini penting untuk dilakukan dalam konteks masa kini. Pertama, untuk membangun landasan konseptual dan legalitas yang jelas terhadap gagasan negara maritim. Kedua, untuk menerapkan secara praktikal gagasan negara maritim dalam pembangunan ekonomi, politik, sosial, dan budaya. Dengan melakukan revitalisasi dan reinterpretasi paradigma maritim yang sesuai dengan jatidiri bangsa maka diharapkan pembangunan nasional berdasarkan kerangka negara maritim mencapai hasil yang optimal
}

Keywords: maritime paradigm; maritime state; sea; national development

Kata kunci: paradigma maritim; negara maritim; laut; pembangunan nasional 


\section{Pengantar}

Tujuan utama makalah ini adalah untuk menunjukkan kembali pentingnya paradigma maritim dalam pembangunan nasional Indonesia dalam rangka mencapai kemakmuran dan kejayaan Indonesia sebagai negara maritim. Apa yang disebut sebagai paradigma maritim di sini adalah pola pikir (pattern of thought) cara pandang terhadap diri dan lingkungannya sebagai bangsa dan negara maritim yang akan mempengaruhinya dalam berpikir (kognitif), bersikap (afektif), dan bertingkah laku (konatif). Paradigma maritim atau yang pernah disebut sebagai wawasan bahari atau wawasan nusantara sebetulnya merupakan konsep pembangunan yang didasarkan pada jatidiri bangsa Indonesia sebagai bangsa maritim yang bersumber dari perjalanan sejarah sebagai komuntas bangsa. Reinterpretasi terhadap wawasan bahari ini sangat penting untuk dilakukan mengingat bahwa keberadaan Indonesia saat ini sebagai negara maritim masih terus diperdebatkan. Hal itu menunjukkan bahwa Indonesia masih berada di dalam persimpangan jalan antara pembangunan menuju negara maritim dan negara agraris.

Perdebatan-perdebatan tersebut juga terkait dengan persoalan konsep dasar mengenai negara maritim Indonesia itu sendiri yang hanya berupa wacana namun tidak bisa dipraktikkan dalam kehidupan kenegaraan. Hal itu pula yang menyebabkan meskipun telah banyak keinginan untuk membangun diri sebagai negara maritim namun hal itu tidak didukung oleh landasan konseptual dan legalitas yang jelas. Landasan pola pikir dan konseptual yang belum jelas menyebabkan strategi untuk membangun Indonesia sebagai negara maritim juga menghadapi persoalan. Salah seorang pakar Hukum Laut Internasional senior, Hasyim Djalal, menyatakan bahwa hingga kini Indonessia sebagai negara kepulauan terbesar di dunia belum mampu menjadi negara maritim dengan indikator bahwa Indonesia belum mampu memanfaatkan potensi sumberdaya yang ada di laut. ${ }^{1}$

Pemahaman yang keliru terhadap hakekat negara maritim juga menyebabkan timbulnya pemikiran yang dikotomis yang mempertentangkan antara kehidupan agraris dan maritim. Pola pikir yang dikotomis dan hitamputih justru menjadi salah satu penyebab pengelolaan sumberdaya baik darat maupun laut yang melimpah menjadi tidak optimal yang berujung pada ketidakmandirian bangsa dan negara Indonesia. Indonesia menjadi bangsa miskin yang hidup di negeri kaya. Oleh sebab itu sangat penting untuk melakukan revitalisasi dan reinterpretasi paradigma pembangunan negara yang sesuai dengan jatidiri bangsa yang memungkinkan tercapainya hasil yang optimal. Berdasarkan potensi geografis dan fakta historis, dapat

1) Hingga saat ini strategi maritim yang semestinya tercakup dalam ocean policy belum juga terwujud. Lihat "Pakar: perlu membangun strategi maritim yang berdaulat", dalam: http://www.antaranews.com/berita/297480/pakar--perlu-membangun-strategimaritim-yang-berdaulat (Dikunjungi 15 Januari 2015) 
dikatakan bahwa semestinya Indonesia bisa menjadi negara maritim yang besar dan kuat. Namun demikian untuk membangun negara maritim yang kuat harus didukung paradigma maritim yang kuat pula dalam proses pembangunan nasional.

\section{Formasi sebagai Bangsa Maritim}

Seperti diketahui bahwa kepulauan Indonesia membentang di perairan tropis antara Samudera Hindia dan Pasifik, dan dari Asia Tenggara hingga Australia Utara. Hal ini tidak mengherankan jika Indonesia dijuluki sebagai negara kepulauan terluas di dunia. Kepulauan Indonesia memiliki luas tanah pulau-pulau sekitar 1,92 juta $\mathrm{km}^{2}$, wilayah laut pedalaman dan laut teritorial 12 mil seluas 3,1 juta $\mathrm{km}^{2}$, dan wilayah Zona Ekonomi Eksklusif (ZEE) 200 mil seluas 2,7 juta $\mathrm{km}^{2}$. Indonesia memiliki garis pantai sepanjang sekitar $81.000 \mathrm{~km}$ sehingga merupakan negara yang memiliki garis pantai tropis terpanjang di dunia. Jarak wilayah Indonesia dari barat ke timur lebih panjang daripada jarak dari London ke Moskow atau dari New York ke San Francisco (Purwaka, 1989: 3-5).

Karakter kepulauan dari wilayah Indonesia telah memungkinkan adanya akses yang sangat mudah bagi pengaruh asing. Fakta bahwa kepulauan Indonesia (Nusantara) menghasilkan banyak komoditas berlimpah telah menarik para pedagang dan penakluk asing untuk datang. Hal ini mengakibatkan pulau-pulau dan laut di Nusantara menjadi medan pertempuran bagi banyak kekuatan. Selain itu, signifikansi ekonomi dari kepulauan Indonesia juga terletak pada fakta bahwa kawasan yang subur ini telah menghasilkan komoditas yang sangat melimpah dan dibutuhkan oleh negara-negara industri pada zaman modern (Broek, 1942: 3).

Iklim tropis yang basah sangat dominan di kepulauan Indonesia. Perubahan iklim terutama tergantung pada angin muson. Hanya ada dua musim yang dikenal di Indonesia, yaitu musim kemarau dan musim penghujan. Musim hujan berlangsung dari Oktober sampai April sebagai hasil dari bertiupnya angin muson barat laut yang basah yang mulai bertiup pada bulan September. Musim hujan berakhir ketika angin muson ini berhenti. Hal ini diikuti oleh datangnya muson tenggara yang kering yang bertiup dari Australia pada bulan Juni dan berakhir pada bulan September. Dalam sejarah Indonesia, kegiatan pelayaran dan perdagangan tradisional biasa memanfaatkan perubahan-perubahan arah angin yang secara periodik berganti arah. Dengan demikian dapat dikatakan bahwa siklus angin muson di perairan kepulauan Indonesia telah memungkinkan terjadinya pelayaran dan perdagangan antarpulau di kawasan ini. Kegiatan maritim ini menjadi media hubungan antarpulau di Nusantara dan antara Nusantara dengan kawasan di sekitarnya. Faktor geografis dan klimatologis inilah yang 'mentakdirkan' kepulauan Indonesia menjadi bagian inheren dari sistem 
jaringan pelayaran dan perdagangan maritim internasional.

'Takdir sejarah' sebagai bangsa pelaut juga bisa dilihat dari asal-usul nenek moyang bangsa Indonesia. Sebagaimana disinggung sebelumnya bahwa karakter terbuka dari geografi kepulauan Indonesia telah memungkinkan terjadinya fenomena diaspora maritim sebagai fenomena yang setua dengan keberadaan bangsa Indonesia itu sendiri, karena nenek moyang bangsa Indonesia sesungguhnya merupakan para pendatang. Para paleontolog berkeyakinan bahwa homo sapien atau hominid yang merupakan nenek moyang langsung dari manusia modern berevolusi di Afrika dan menyebar dari sana ke seluruh dunia termasuk ke kepulauan Indonesia. Sisa-sisa fosil di lembah sungai Brantas di Jawa Tengah dan Jawa Timur memberikan petunjuk bahwa keberadaan hominid sudah ada sejak sekitar 1,8 juta tahun yang lalu. Penemuan sisa-sisa manusia purba (yang kemudian disebut sebagai 'Manusia Jawa') oleh Eugene Dubois di Trinil di Jawa Timur pada tahun 1891 membuktikan hal itu (Cribb, 2000). ${ }^{2}$

Dalam hal ini apakah 'Manusia Jawa' merupakan nenek moyang manusia pertama (Homo sapiens) dari masyarakat di kepulauan Indonesia masih belum dapat dipastikan, meskipun sisa-sisa manusia Jawa lainnya ditemukan dari periode hingga sekitar 100.000 tahun yang lalu yang mewakili masa transisi antara Homo erectus dan manusia awal yang sesungguhnya, yang jejaknya yang paling awal berasal dari sekitar 40.000 tahun yang lalu. Para paleontolog juga menyatakan bahwa tidak ada alasan untuk meragukan bahwa mereka merupakan manusia pertama dari kelompok etnis yang luas yang sekarang disebut Australo-Melanesia dan bahwa mereka adalah nenek moyang dari Melanesia di Papua Nugini, suku bangsa Aborigin Australia dan masyarakat kecil Negrito di Semenanjung Melayu dan Filipina.

Para pakar geomorfologi menyatakan bahwa iklim global telah berubah beberapa kali selama 40.000 tahun terakhir dan perubahan ini memiliki pengaruh yang besar terhadap manusia purba. Sebagai pemburu dan pengumpul, mereka mungkin melakukan yang terbaik di hutan yang relatif terbuka, sepanjang pantai dan di pinggiran hutan tropis. Oleh karena kenaikan permukaan air laut setelah berakhirnya zaman es terakhir, pemukiman manusia tampaknya telah terkonsentrasi di kawasan yang lebih kering di bagian timur Nusantara. Pada sekitar tahun 7000 SM di dataran tinggi Papua, orang-orang Melanesia telah mengembangkan teknologi pertanian dengan menanam talas, pisang, dan ubi-ubian. Pengembangan pertanian ini semakin memperkuat kehadiran orang-orang Melanesia di bagian timur Nusantara.

Sejak sekitar 3000 SM, orang-orang dari varian Mongoloid dari bagian

2) Sebagian besar informasi mengenai persebaran bangsa Austronesia di kawasan kepulauan Indonesia pada bagian ini diambil dari Robert Cribb, Historical Atlas of Indonesia (Singapore: Cuzon Press, 2000). 
selatan Cina, yang dikenal sebagai bangsa Austronesia, mulai bergerak ke selatan dalam jumlah besar. Orang Austronesia membawa teknologi seperti kemampuan untuk membuat kano bercadik, tembikar, busur, dan anak panah, tradisi memelihara babi, unggas, dan anjing, dan mereka bercocok tanam padi dan gandum. Pada saat itu, beras dan gandum cocok untuk ditanam di daerah tropis dan sub-tropis. Mereka juga memiliki kebiasaan makan talas, sukun, pisang, singkong, sagu, dan kelapa.

Gelombang diaspora Austronesia terbagi menjadi dua ketika mereka mencapai pantai Papua. Beberapa dari mereka terus bermigrasi ke timur hingga mencapai Fiji dan Tonga sekitar 1500 SM. Keturunan mereka menghuni kawasan kepulauan di Samudera Pasifik yang membentang sejauh Selandia Baru, Pulau Paskah dan Hawaii. Diaspora Austronesia yang menuju ke arah barat akhirnya mencapai Jawa, Sumatera, Kalimantan, dan Semenanjung Melayu. Beberapa dari mereka menetap di Asia Tenggara daratan dan menjadi nenek moyang orang Champa yang masih merupakan minoritas kecil di selatan Vietnam. Pada periode berikutnya, serangkaian diaspora yang dimulai sekitar abad ke lima Masehi dan berakhir pada abad kedua belas, orang-orang Austronesia mulai bermukim di pulau Madagaskar. Sangat menarik bahwa pada kenyataannya penyebaran bangsa Austronesia, membentang lebih dari setengah keliling bumi dan ini adalah salah satu diaspora manusia yang paling spektakuler sebelum era modern.

Dalam jangka yang panjang, gelombang diaspora juga telah menimbulkan keanekaragaman bahasa dan suku bangsa. Pada awalnya para diaspor Austronesia di Nusantara mungkin berbicara dalam satu bahasa. Namun demikian, selama berabad-abad kelompok-kelompok diaspora yang berbeda-beda kehilangan kontak antara yang satu dengan yang lain sehingga semakin lama bahasa mereka semakin berkembang dan timbul perbedaanperbedaan di antara bahasa mereka. Bahasa dapat berubah dengan cepat meskipun kemunculan dialek masih dengan mudah dapat saling dimengerti dalam beberapa abad. Namun demikian hampir tidak ada catatan dari proses perubahan bahasa di Nusantara sebelum 1800. Pada masa Indonesia modern sekarang ini, masih terdapat sekitar 200 rumpun bahasa Austronesia dan lebih dari 150 rumpun bahasa Papua (Melanesia). Sebagian besar ahli bahasa telah dapat mengelompokkan bahasa-bahasa di Nusantara ke dalam kelompok yang lebih besar yang hampir pasti mengindikasikan keturunan dari leluhur yang memiliki kesamaan bahasa (Drake, 1989: 6; Soarez, 1999: 16).

\section{Di tengah Kancah Perdagangan Internasional}

Situasi ekonomi penduduk di kepulauan Indonesia beragam sesuai dengan subvariasi iklim dan jenis serta tingkat kesuburan tanah yang dipengaruhi oleh kegiatan vulkanik. Sejak zaman kuno Jawa merupakan eksportir 
utama komoditas beras. Pulau-pulau di kawasan kepulauan Maluku dikenal sebagai penghasil rempah-rempah. Sementara itu, Sumatera (terutama Aceh dan Sumatera Selatan) menghasilkan lada yang sangat dibutuhkan dalam perdagangan antara Barat dan Timur. Jawa dalam hal ini memainkan peranan penting sebagai katalisator antara pulau-pulau di Nusantara (timur) dengan negara-negara di Barat.

Indonesia memiliki posisi strategis geografis di sepanjang rute perdagangan maritim internasional (silk road) antara dua negara adidaya pada saat itu, yaitu India dan Cina. Oleh karena itu, bukan suatu kebetulan jika penduduk Nusantara secara aktif mengambil bagian dalam perdagangan. Apalagi para penghuni Nusantara merupakan keturunan suku bangsa perantau yang spektakuler. Bukti sejarah menunjukkan bahwa sejak abad ke-2 Masehi telah terjadi hubungan dagang antara Nusantara dan India. Selain itu, sejak abad ke-5 berbagai negara di Nusantara telah mengirim utusan dagang ke Cina. Produk yang diperdagangkan pada saat itu lada, cengkeh, pala, kayu cendana, beras, kain, dan sebagainya.

Pada saat itu India dan Cina adalah dua negara adidaya maju dan kaya. Di antara mereka terjalin hubungan perdagangan yang erat yang pada gilirannya juga melibatkan negara-negara sekitarnya, termasuk berbagai kerajaan maritim di Nusantara, seperti Sriwijaya di Sumatera (abad ke-7 hingga 13) dan kerajaan Singasari - Kediri - Majapahit di Jawa ( abad 12 - 15). Rempah-rempah (cengkeh, pala) dari Maluku, lada dari Aceh, Sumatera Selatan, Jawa Barat, adalah komoditas yang populer di manamana. Sandalwood Nusa Tenggara, kemenyan dari Sumatera, Kalimantan, dan Sulawesi juga dibutuhkan oleh orang-orang dari India dan Cina untuk keperluan upacara keagamaan. Sebaliknya, barang-barang dari Cina juga dibutuhkan oleh orang-orang dari kepulauan Indonesia, terutama demi prestise di kalangan elit. Komoditas dari Cina yang sangat populer di kepulauan Indonesia adalah sutra dan barang-barang porselen seperti piring, mangkuk, gelas, vas, dan sebagainya. Sementara itu, pedagang India menjual kain yang berkualitas baik.

Selama ekspansi Islam ke timur, perdagangan juga dimeriahkan oleh negara-negara lain di Asia seperti Arab, Iran, Turki, India Muslim, dan sebagainya (Curtin, 1998: 109-127; Soeroto, 1976: 11). Fenomena ini juga mendorong munculnya kerajaan maritim yang bercorak Islam di kepulauan Indonesia seperti dari Samudera Pasai (abad ke-13), Kesultanan Aceh (14961903), Kesultanan Palembang (abad ke-17 - 19) di Sumatera; Kesultanan Demak (abad ke-15 - 16), Kesultanan Cirebon (sejak abad ke-15), Kesultanan Banten (abad ke-16 - 19), dan sebagainya; Kesultanan Banjarmasin (abad ke-16 -19) di Kalimantan, Kerajaan Gowa di Sulawesi (sejak abad ke-14), Kesultanan Ternate dan Tidore di kepulauan Maluku (sejak abad ke-13), dan sebagainya. 
Salah satu kekuatan dinamis dalam pelayaran dan perdagangan antarpulau adalah saling ketergantungan pasokan dan permintaan antar daerah di kepulauan Indonesia. Sejak era prakolonial, Jawa memasok beras ke pulau-pulau lain di Nusantara seperti kepulauan Maluku dan bahkan Malaka. Pulau-pulau selain Jawa memproduksi rempah-rempah dan berbagai jenis hasil hutan. Orang-orang di Jawa tidak mengkonsumsi komoditas ini dalam skala besar namun diekspor kembali ke negara-negara di sebelah barat Nusantara. Terjadilah semacam barter, di mana orang lokal memperoleh tekstil, barang logam, perhiasan, dan sebagainya dengan menjual rempahrempah. Secara singkat dapat dikatakan bahwa telah terjadi terjadi semacam spesialisasi dalam supply and demand dalam sistem perdagangan antarpulau di kepulauan Indonesia.

\section{A. Sriwijaya: Resposif terhadap Lingkungan Geostrategis}

Para sejarawan mengakui bahwa Sriwijaya pernah menjadi kerajaan bahari terbesar di Asia Tenggara sekitar abad ke-7 hingga ke-12. Salah satu kunci keberhasilan Sriwijaya menjadi sebuah negara maritim yang besar pada zamannya adalah kebijakan dan sikap yang responsif terhadap terhadap lingkungan geostrategisnya. Dalam hal ini, Sriwijaya yang memiliki posisi yang strategis tidak menjadi objek yang pasif. Hasil-hasil kebudayaan yang berkembang pada waktu itu menunjukkan tentang adanya peran yang signifikan orang-orang lokal dalam proses akulturasi kebudayaan di kawasan ini, khususnya antara budaya lokal dengan budaya India. Seperti diketahui bahwa pada abad ke-2 masehi hubungan dagang antara Nusantara dan India sudah relatif intensif sehingga pada abad ke- 5 masehi pengaruh perdagangan itu telah menembus pada segi-segi kehidupan sosial, kebudayaan dan agama penduduk Nusantara dengan munculnya kerajaan-kerajaan yang menunjukkan pengaruh kebudayaan Hindu dan Budha (Coedes, 1968 : 20). Oleh karena itu tidak mengherankan jika pada periode itu telah muncul beberapa kerajaan yang menunjukkan adanya pengaruh luar (terutama India) seperti kerajaan Kutai di Kalimantan Timur dan Tarumanegara di Jawa Barat, Mataram di Jawa Tengah, dan kemudian disusul Kerajaan Sriwijaya sekitar abad ke-7.

Dalam hal ini orang-orang Sriwijaya tidak hanya menunggu para pedagang asing datang menjual dan membeli barang, tetapi dalam perkembangan selanjutnnya mereka juga menjadi pemain yang menentukan sebagai pelaut dan pedagang yang ulung. Hampir bisa dipastikan bahwa pada awal abad ke-5 telah ada orang-orang Nusantara yang datang berlayar/ berdagang langsung ke Cina. Sebuah berita Cina menceritakan bahwa pada bulan ke empat tahun 430 datanglah utusan dari Ho-lo-tan, sebuah negeri di Shê-p'o (Jawa). Jadi jelas bahwa utusan itu datang dari Nusantara yang membawa kain dari India dan Gandhara. Secara berturut-turut, Ho-lo- 
tan mengirimkan utusan ke Cina pada tahun 430, 433, 434, 436, 437, dan 452 (Wolters, 1967: 164). Diperkirakan bahwa Holotan (atau Aruteun) merupakan pendahulu kerajaan Taruma sebelum kerajaan ini mendapat pengaruh Hindu. Berita Cina mengenai Taruma sendiri terutama terjadi setelah periode Ho-lo-tan. ${ }^{3}$ Dari berbagai berita Cina dapat disimpulkan bahwa bahwa pada abad ke-5 masehi orang-orang Nusantara sudah memiliki hubungan dagang langsung dengan Cina. Hubungan dagang itu bahkan lebih banyak merupakan hasil dari inisiatif orang Nusantara dengan melihat banyaknya utusan dagang ke Cina tersebut. Sementara itu kaisar Cina hanya sesekali mengirimkan utusan ke negeri-negeri di Nusantara dan itupun banyak berurusan dengan soal agama dan politik. Baru dalam tahap berikutnya, datang juga para pedagang Cina ke pelabuhan-pelabuhan di Nusantara. Setelah penduduk Nusantara dapat berdagang langsung dengan Cina, maka ia mendapat kedudukan yang penting dalam jaringan perdagangan dan pelayaran internasional. Kapal-kapal Indonesia lalu-lalang melayari perairan antara India dan Cina. Pada abad ke-7 masehi seorang pendeta Budha dari Cina yang bernama I-tsing bertolak ke India dari Indonesia dengan menumpang kapal Sriwijaya (Kartodirjo, Poesponegoro, Notosusanto, 1975: 19).

Muncul dan berkembangnya Sriwijaya terkait erat dengan perdagangan yang sedang berkembang di sepanjang jaringan maritim antara India dan Cina, antara Nusantara dan Cina, dan perdagangan intra-regional di Asia Tenggara. Di antara faktor yang paling penting dalam kebangkitan Sriwijaya sebagai pusat perdagangan maritim di Asia Tenggara adalah kemampuan mereka untuk mengontrol wilayah pedalaman mereka sendiri di Sumatra dan kemampuannya untuk mendominasi kota-kota pelabuhan saingannya dan dengan demikian secara tidak langsung juga mengontrol daerah-daerah pedalaman mereka. Kontrol ini memungkinkan Sriwijaya untuk menguasai dan memusatkan perdagangan produk pertanian, hutan, dan produk-produk laut kepulauan Indonesia di pelabuhan-pelabuhan yang dikuasai Sriwijaya. Selain itu, Sriwijaya juga mengembangkan sistem politik yang didasarkan pada kesetiaan dan kontrol terhadap sumber daya perdagangan. Lokasi Sriwijaya itu sendiri sebenarnya relatif tidak strategis karena terletak jauh dari Selat Malaka. Dengan memanfaatkan kekuatan armadanya, akhirnya Sriwijaya bisa mengontrol perdagangan di bagian barat kepulauan Indonesia (Manguin, 1993: 33).

3) Utusan terakhir kerajaan To-lo-mo ke Cina tahun 669. Sesudah itu nama To-lo-mo tidak terdengar lagi. Mungkin sekali kerajaan ini ditaklukkan oleh Sriwijaya. Dalam prasati Kota Kapur yang berbahasa Melayu Kuno dan berhuruf Pallawa disebutkan bahwa pada tahun 686 tentara Sriwijaya berangkat menyerang Bhumi Jawa yang tidak tunduk kepada kerajaan Sriwijaya. Mengenai hal ini lihat Irfan, Kerajaan Sriwijaya, hlm. 39-41. Lihat juga C.O. Blagden, 'The Kota Kapur (Western Bangka) Inscription', JMBRAS 64 (1913), hlm. 69-71. 
Selain itu, mereka juga mampu melindungi perairan mereka melawan bajak laut dan kemungkinan serangan dari negara lain. Sebagai negara maritim, Sriwijaya telah menerapkan strategi untuk bertahan hidup dan memperluas kekuasaan. Untuk kelangsungan hidupnya, Sriwijaya menjalin hubungan diplomatik internasional dengan dua 'kekuatan super', yaitu Cina dan India yang diperkirakan menjadi potensi ancaman. Diplomasi dengan India, misalnya, dibangun dengan mendirikan sebuah vihara di Nalanda selama pemerintahan Balaputradewa. Diplomasi dengan Cina dibangun dengan mengirim upeti kepada kaisar Cina. Setiap kali Sriwijaya mendapat ancaman dari musuh-musuhnya, ia selalu meminta perlindungan dari Cina. Sriwijaya mengakui Cina sebagai pelindung dan mengirimkan upeti kepada kaisar Cina. Dengan mengambil berbagai kebijakan seperti itu, Sriwijaya merasa aman dari bahaya ekspansi militer Cina yang telah jauh mencapai Vietnam dan Fu-Nan. Selain itu, kapal-kapal Sriwijaya akan mendapatkan perlakuan yang lebih baik ketika mereka berlabuh di pelabuhan-pelabuhan Cina (Wolters, 1967: 152).

Di sisi lain, pada level regional Sriwijaya meneguhkan kekuatannya dan bahkan melakukan ekspansi ke wilayah sekitarnya di kawasan dunia Melayu. Secara berangsur-angsur Sriwijaya akhirnya dapat mengendalikan pusat-pusat perdagangan dan lalu-lintas pelayaran di sekitarnya dengan kekuatan militer (Christie, 1999: 221-2). Dengan cara seperti itu Sriwijaya mampu mengontrol pusat-pusat perdagangan di Semenanjung Malaya seperti P'eng-feng (Pahang), Teng-ya-Nung (Trengganu), Ling-Ya-SuChia (Langkasuka), Chi-lan-tan (Kelantan), Fo-lo-an (Kuala Berang), Tanma-ling (Tambralingga, Ligor), Chia-lo-si (Grahi, Teluk Brandon) (Bradell, 1936: 1-71). Dengan demikian kerajaan ini telah menjadi kerajaan maritim terbesar di kawasan Selat Malaka.

\section{B. Majapahit: Sinergitas Daratan dan Lautan}

Sriwijaya yang berkembang pesat di dunia Melayu ini sejalan dengan perkembangan kekuasaan politik kerajaan-kerajaan di Jawa. Kompetisi dan konflik antara Sriwijaya dan kerajaan-kerajaan di Jawa menunjukkan intensitas tinggi ketika pusat kerajaan Mataram dipindahkan dari Jawa Tengah ke Jawa Timur. Raja Sendok (929-947), telah memindahkan istana dan ia diakui sebagai pendiri dinasti baru (Isyana) yang memerintah di Jawa Timur sampai 1222. Salah satu motif pemindahan ini adalah untuk menghindari konflik dengan Sriwijaya. Munculnya kekuatan politik di Jawa Timur memberikan dampak yang signifikan bagi perekonomian daerah di kawasan pantura Jawa bagian timur pada khususnya dan kepulauan Indonesia pada umumnya (Wolters, 1979: 6; Wales, 1978: 5). Berbeda dengan kerajaan Mataram di Jawa Tengah yang diyakini sangat bergantung pada ekonomi pertanian sawah, wilayah pesisir dan lembah-lembah 
sungai di Jawa Timur pada waktu itu belum berkembang sebagai daerahdaerah pertanian yang surplus yang dapat mendukung kekuatan politik kerajaan baru ini. Oleh karena itu, sejak periode awal raja-raja Jawa Timur memberi perhatian yang lebih terhadap perdagangan maritim. Hubungan perdagangan diselenggarakan baik dengan kawasan timur kepulauan Indonesia (seperti Maluku) maupun dengan kawasan bagian barat (seperti dengan orang-orang Sumatra dan Semenanjung Malaya yang pada waktu itu masih di bawah dikuasai oleh kerajaan Sriwijaya). Persaingan dan konflik militer kemaritiman antara kekuatan Jawa dan Sriwijaya memuncak pada masa Jawa berada di bawah kerajaan Majapahit sejak akhir abad ke-13.

Jika pada masa kerajaan Singasari (pendahulu Majapahit) upaya untuk melakukan ekspansi maritim ke kawasan Nusantara bertujuan untuk menjadikan seluruh Nusantara di bawah lindungan Singasari untuk menghadapi ekspansi Mongol, maka ekspansi yang dilakukan oleh Majapahit terutama ditujukan untuk menguasai sumber-sumber ekonomi maritim di Nusantara secara umum. Jika pada masa Kertanegara, Pan-Nusantara dicapai dengan jalan diplomasi yang persuasif untuk menyadarkan adanya bahaya luar, dengan cara membina hubungan spiritual, dan lewat perkawinan politis dan magis dalam rangka untuk menciptakan front antiekspansi Mongol di Asia Tenggara, maka Pan-Nusantara jaman Majapahit dilanjutkan dengan peneguhan kekuasaan secara politik dan dalam beberapa kasus juga dengan cara-cara militer. Di dalam kitab Pararaton dan Negarakertagama disebutkan sekitar 98 daerah vassal Majapahit antara lain Palembang, Jambi, Kampar, Siak, Rokan, Lamuri, Barus, Haru di Sumatra; Pahang, Kelang, Sai dan Trengganu di Semenanjung Malaya; Sampit, Kapuas, Barito, Kutai and Sedu di pulau Kalimantan; Butung, Luwuk, Banggai, Tabalong di Sulawesi; Wandan di Maluku; Seran di Irian; Sumba dan Timor di Nusatenggara. ${ }^{4}$

Di samping itu juga diinformasikan mengenai negara-negara sahabat Majapahit seperti Siam, Burma, Champa, Vietnam, Cina, dan Benggala. Negara-negara sahabat ini memiliki hubungan ekonomi dengan Majapahit (Kartodirjo, Poesponegoro, Notosusanto, 1975: 85). Meskipun daftar kerajaan yang berada di bawah kekuasaan Majapahit itu banyak yang meragukan, namun tidak ada alasan untuk meragukan bahwa tempattempat yang disebutkan dalam daftar itu telah dihubungkan dengan jaringan maritim lewat aktivitas perdagangan. ${ }^{5}$ Bahkan ekspedisi Cheng Ho antara

4) Lihat A.B. Lapian, 'The maritime network in the Indonesian archipelago in the fourteenth century', in: SEAMEO Project in Archeology and Fine Arts SPAFA, Final report: Consultative workshop on research on maritime shipping and trade networks in Southeast Asia (Cisarua, West Java, Indonesia: 20-27 November 1984) 71-80. Mengenai beberapa catatan mengenai pengaruh Majapahit di Semenanjung Melayu berdasarkan sumber-sumber tradisional lihat C.O. Blagden, 'Notes on Malay History', JMBRAS 53 (1909), hlm. 139-162.

5) Ahli yang meragukan kebesaran Majapahit antara lain C.C. Berg, 'De Sadeng Oorlog en de Myth of Great Majapahit', Indonesia 5 (1951/52), hlm. 385-dst. 
tahun 1405 dan 1433, yaitu ketika Majapahit sudah mulai melemah, mengakui bahwa perdagangan Jawa masih kuat dan bersumber dari kemampuan pelayarannya sendiri. Bahkan misi dagang ke Cina dipandangnya bertujuan untuk mengembangkan perdagangan lokal mereka sendiri.

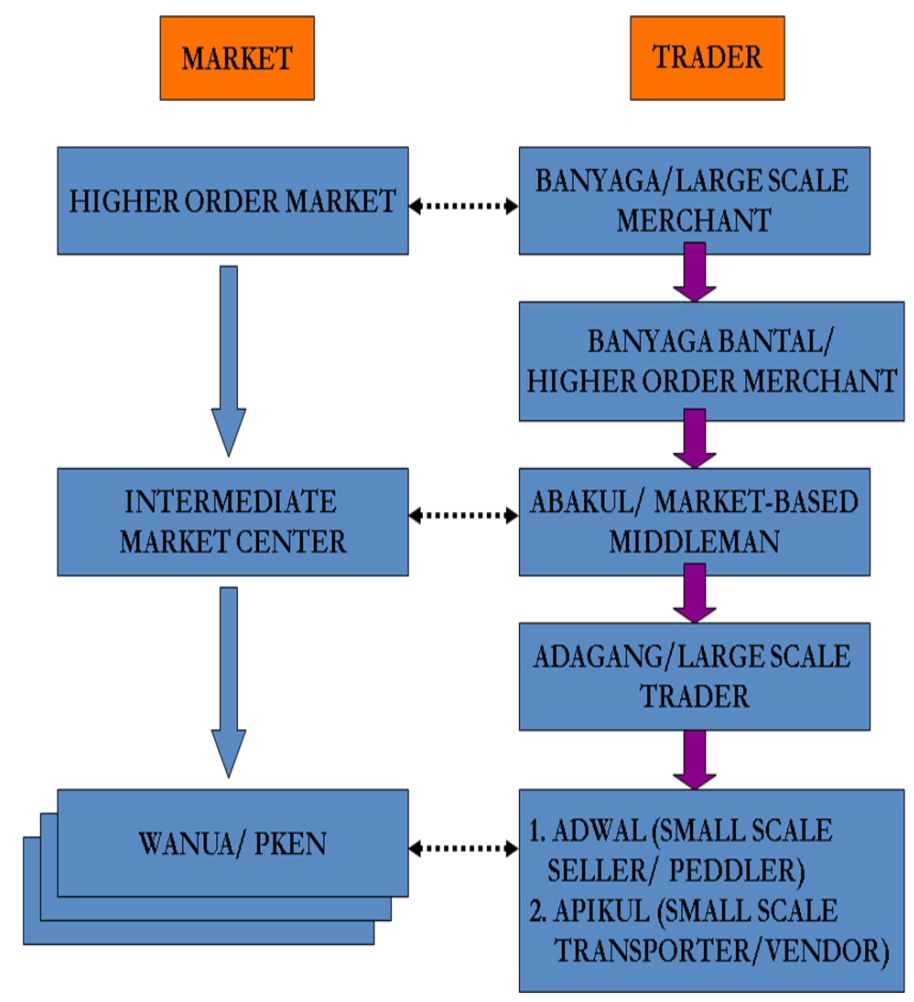

Figur 1.

Struktur Pasar di Majapahit.

Sumber: Hall, Maritime Trade, hlm. 25

Kampanye Majapahit untuk melakukan ekspansi ke kawasan seberang dimulai sekitar tahun 1347. Politik ekspansi ini telah diletakkan oleh Mahapatih Gajah Mada. Dalam sumber-sumber tradisional ia diceritakan telah mengucapkan sumpah untuk tidak makan buah palapa atau tidak akan menikmati kesenangan hingga seluruh wilayah Nusantara berada di bawah kekuasaan Majapahit. Sebagaimana dikatakan sebelumnya bahwa bagaimana persisnya wilayah kekuasaan kerajaan Majapahit masih merupakan kontroversi. Namun demikian hampir tidak bisa diragukan bahwa tentunya armada laut Majapahit secara periodik melakukan kunjungan ke berbagai wilayah di Nusantara untuk memperoleh pengakuan formal atau sekedar pamer kemegahan armada kerajaan sehingga mendorong penguasa lokal untuk memberikan upeti kepada Majapahit mungkin secara sukarela. Sudah barang tentu kekuatan jaringan dan armada dagang Majapahit akan mampu memberikan sanksi kepada penguasa lain yang menunjukkan sikap bermusuhan kepada Majapahit.

Dalam salah satu ulasannya mengenai perkembangan kota Malaka sejak akhir abad ke-14, R.J. Wilkinson mengatakan bahwa kota ini berkembang dari sebuah desa nelayan yang dihuni oleh suku Sakai-Laut (Orang Laut) menjadi kota perdagangan yang penting adalah sebagai akibat dari ekspansi yang dilakukan oleh kerajaan Majapahit terhadap berbagai kota penting di sekitar Selat Malaka. Dia menggambarkan bahwa secara tiba-tiba Majapahit menempatkan diri sebagai bangsa penakluk di 
kawasan Asia Tenggara. Dengan menggunakan armadanya, Majapahit telah menyapu sisa-sisa pusat kerajaan Sriwijaya di Palembang. Selain itu armada Majapahit juga melakukan penaklukan terhadap Singapura. Demikian juga ekspedisi Majapahit juga telah menaklukkan pelabuhan penting di ujung utara Sumatra yaitu Pasai dan selanjutnya Langkasuka (Ligor). Rangkaian penaklukan terhadap kota-kota pelabuhan tersebut (antara tahun 13701380) menurut Wilkinson telah mendorong berkembangnya kota Malaka. Perkembangan ini berkaitan dengan migrasi para pedagang dari kota-kota itu menuju ke Malaka dan selanjutnya menjadikanya sebagai kota dagang internasional yang bersifat kosmopolitan. Jadi rangkaian penaklukan Majapahit mendorong perkembangan kota Malaka yang menurut sumbersumber lokal juga didirikan oleh keturunan orang Majapahit dari Palembang (Wilkinson, 1912: 67-71).

Ada pula yang menyangsikan apakah memang betul bahwa Majapahit merupakan kerajaan maritim mengingat ibukota majapahit itu sendiri tidak terletak di tepi pantai, tetapi berada di pedalaman. Berdasarkan catatan $\mathrm{Ma}$ Huan yang menyertai ekpedisi Cheng Ho pada waktu Majapahit masih berdiri dapat diketahui adanya informasi bahwa Majapahit memiliki empat kota penting yaitu Tu-Pan (Tuban), Ko-erh-his (Gresik), Su-erh-pa-ya (Surabaya), dan ibukota Man-che-po-I (Majapahit). Ma Huan juga mengambarkan berbagai tempat yang merupakan pintu gerbang menuju ibukota Majapahit. Ia mengatakan bahwa dari Surabaya kapal-kapal kecil dapat berlayar sejauh 70 hingga 80 li (sekitar sepertiga mile) hingga mencapai pelabuhan Canggu sebagai tempat berlabuh. Selanjutnya perjalanan menuju ke arah baratdaya selama satu setengah hari akan mencapai ibukota Majapahit (Colless, 1975: 130). Dari keterangan Ma Huan tersebut dapat disimpulkan bahwa memang betul ibukota Majapahit berada di pedalaman namun sebagian perjalannya masih bisa ditempuh dengan menggunakan kapal kecil. Dari segi geostrategi, letak ibukota yang demikian ini justru sangat menguntungkan mengingat bahwa ibukota kerajaan yang berada di tepi pantai akan lebih rentan terhadap serangan musuh dari laut yang sangat terbuka. Hal ini juga sama dengan Cina yang meskipun ibukotanya ada di pedalaman namun tidak selalu berarti menjauhkan diri dari aktivitas kebaharian. Selain itu Majapahit juga memiliki pelabuhan-pelabuhan penting sebagai pusat kegiatan kemaritiman seperti Tuban, Canggu, Gresik, Surabaya, dan sebagainya.

Pentingnya transportasi laut dan sungai bisa diterima secara akal sehat mengingat wilayah Majapahit khususnya daerah di sekitar ibukota merupakan hutan pegunungan dengan sungai-sungai besar. Di sini peranan sungai Brantas sebagai media transportasi menjadi sangat penting. Pada waktu itu kapal-kapal laut masih bisa berlabuh di pelabuhan Canggu yang merupakan pelabuhan sungai besar yang dekat dengan ibukota Majapahit. Duarte Barbosa yang pernah singgah di Jawa pada perempatan pertama abad 
ke-16 mengatakan bahwa di samping memiliki jung-jung untuk pelayaran samudera, orang-orang Jawa juga memiliki kapal yang 'well-built light vessels propelled by oars' yang biasanya digunakan untuk aktivitas perompakan (Colless, 1975: 132). Kemampuan armada dagang Majapahit tidak dapat diragunakan lagi untuk melayari laut-laut di Nusantara tetapi juga samudera lepas dalam perdagangan internasional. Tome Pires yang datang di Jawa pada awal abad ke-16 mengatakan bahwa seratus tahun sebelum ia datang, Jawa memiliki kekuasaan yang sangat besar di mana kapal-kapalnya berlayar hingga mencapai Aden dan Majapahit memiliki hubungan dagang utama dengan kerajaan Keling (India), Benggala, dan Pasai (Sumatra). Ia menambahkan bahwa:

'it had the whole of the trade at that time...gathered together such great merchants with so much trade along its sea coasts, that nowhere else so large so rich was known. Some of them were Chinese, some Arabs, Parsees, Gujaratees, Belgalees and many other nationalities' (Colless, 1975: 138).

Kerajaan Majapahit berkembang bukan hanya dari basis ekonomi pertanian namun juga pengembangan kegiatan pelayaran dan perdagangan sebagai sebuah negara maritim. Perdagangan laut itu bukan hanya dilakukan antara satu daerah dengan daerah lain di Nusantara, tetapi juga perdagangan internasional dengan kawasan yang lebih luas. Pigeaud berpendapat bahwa barang-barang impor telah dikenal oleh masyarakat Majapahit hingga pedalaman seperti tekstil dari India dan barang-barang dari Cina seperti mata uang, barang-barang pecah belah dan batu mulia (Pigeaud, 1960-1963: 500). Chao Ju-Kua memberikan kesaksian bahwa komoditas Cina yang dibeli oleh para pedagang Jawa mencakup emas, perak, sutera, pernis, dan porselin. Begitu berkembangnya daya beli para pedagang Jawa sehingga menyebabkan Kekaisaran Cina pernah melarang perdagangan dengan Jawa karena menyebabkan terjadinya penyedotan mata uang Cina ke Jawa melalui perdagangan rempah-rempah, khususnya lada (Colless, 1975: 138).

Perlu diingat bahwa Tome Pires yang berkunjung di pelabuhanpelabuhan di Jawa pada awal abad ke-16 mendengarkan dengan telinganya sendiri bahwa kebesaran Majapahit sudah beredar di kalangan banyak orang pada waktu itu. Ia mengatakan bahwa:

They say that the island of Java used to rule as far as the Moluccas (Maluco) on the eastern side and (over) a great part of the west; and that it had almost all this for a long time past until about a hundred years ago, when its power began to diminish until it came to its present state (Cortesao, 1944: 74; Colless, 1975: 124-161). 
Kemunduran Majapahit sebagai akibat dari perebutan kekuasaan di antara para keluarga kraton mengakibatkan ketidakmampuannya untuk mengontrol daerah-daerah yang dikuasai. ${ }^{6} \mathrm{Hal}$ itu sejalan dengan berkembangnya agama Islam di pelabuhan-pelabuhan yang dikuasai Majapahit. Kehancuran internal mendorong pelabuhan-pelabuhan itu memisahkan diri dari Majapahit dan mendapatkan vitalitas baru dari semangat agama Islam. Meskipun entitas politik nasional di Nusantara hancur sejalan dengan hancurnya Majapahit pada akhir abad XV namun jaringan-jaringan dagang semakin berkembang justru karena proses sentrifugal kekuatan politik ini. Dalam hubungan ini proses sentrifugal dalam entitas politik justru diikuti oleh proses integrasi ekonomi.

Kerajaan Majapahit memiliki armada dagang yang mampu berlayar dan sekaligus bersaing di perairan Nusantara dan bahkan mampu mengarungi Lautan Hindia dan Laut Cina Selatan untuk berdagang dengan Cina. Angkatan laut Majapahit mampu untuk mengontrol wilayah dan lalu-lintas laut di sekitar Selat Malaka yang merupakan pintu gerbang perdagangan internasional di kawasan ini. Pada saat yang sama, penduduk Majapahit mampu memproduksi dan menjual komoditi perdagangan yang dibutuhkan oleh pasar iinternasional. Di satu sisi para pedagang dan pelaut dapat memperoleh keuntungan, sedangkan pemerintah dapat menarik pajak dan berbagai pendapatan yang terkait dengan kegiatan perdagangan dan para pemilik kapal memiliki peluang untuk mengembangkan investasi mereka menjadi usaha yang lebih besar. Agar sejalan dengan tuntutan perdagangan internasional misalnya, kerajaan Majapahit melakukan penyesuaian struktural dalam birokrasi dan pasar domestik yang dapat menjadi katalis antara pasar lokal dengan pasar internasional (Hall, 1985: 25). Hal itu bisa dilihat dari keteriringan antara struktur politik dan struktur pasar di Majapahit.

Dengan demikian, perdagangan internasional yang dilakukan oleh para pedagang Majapahit bukan hanya merupakan kegiatan para pedagang dan pelaut itu sendiri, tetapi juga merupakan bagian yang integral dari kegiatan masyarakat dan merupakan bagian dari kegiatan yang berada di bawah kontrol pemerintah. Hal itu berarti bahwa mekanisme sebagai negara maritim melibatkan segenap potensi yang ada di dalam masyarakat sebagai sebuah sistem. Selain itu, kegiatan ekonomi bukan hanya ditujukan semata-mata untuk kepentingan ekspor (export-led economy) tetapi juga untuk kepentingan memenuhi kebutuhan domestik sendiri.

6) Palembang sendiri sebagai bekas pusat kerajaan Sriwijaya diceritakan menjadi sarang dari perompak Cina setelah tahun 1377. Lihat misalnya R.W. McRoberts, 'Notes on Events in Palembang 1389-1511: The Overlasting Colony', JMBRAS 1 (59) (1986), hlm. 73. 


\section{Tantangan Kolonialisme}

Sistem perdagangan maritim mengalami penyesuaian setelah munculnya para pedagang Barat di Nusantara (Manguin, 1993: 198-9). Sebuah sistem perdagangan bersenjata (armed-trading system) yang dikembangkan oleh pelaut Barat menjadi pukulan besar bagi para pedagang lokal, yang telah berkembang selama berabad-abad. Meskipun intervensi kekuatan Barat sangat rumit, namun sebetulnya tidak mengubah pola dasar perdagangan di Nusantara khususnya dan Asia Tenggara umumnya. Penaklukan Malaka oleh Portugis pada tahun 1511 hanya memicu munculnya pusat-pusat perdagangan Islam di Nusantara seperti Aceh, Johor, dan Brunei. Pada saat yang sama, Kristen militan Portugis juga telah peran tertentu dalam merangsang pertumbuhan banyak emporium bercorak Islam di sepanjang pantai utara Jawa seperti Demak, Banten, Cirebon, Surabaya, dan sebaginya. Kehadiran Portugis sebagai pesaing pedagang Muslim di Asia Tenggara secara tidak langsung membantu kebangkitan Jawa setelah jatuhnya kerajaan Majapahit pada akhir abad ke-15. Namun demikian pertumbuhan ekonomi negara-negara pesisir di sepanjang pantai utara Jawa tidak hanya dipandang curiga oleh Portugis di Malaka, tetapi juga oleh Kerajaan Mataram yang terletak di pedalaman Jawa.

Mataram mulai menaklukkan negara-kota tersebut pada awal abad ke16 dengan pengecualian Banten. ${ }^{7}$ Mataram menghancurkan hampir semua sumber daya ekonomi dari negara-negara pesisir sehingga mengakibatkan eksodus para pedagang ke berbagai pelabuhan di luar Jawa, seperti Makassar dan Banjarmasin (Graaf \& Pigeaud, 1989: 24-6; Burger, 1975: 26). Akibatnya semua kota perdagangan di sepanjang pantai utara Jawa, kecuali Banten, dalam keadaan lemah ketika Belanda mulai memperluas monopoli mereka pada abad ke-17.

VOC mulai memaksakan kebijakan monopoli pembelian terhadap orang-orang pribumi. Dengan demikian, berarti mereka juga mengibarkan bendera konflik dengan pedagang Eropa lain. Dalam konteks ini VOC akhirnya menjadi kekuatan yang sewenang-wenang dalam menentukan harga jual produk lokal. VOC melarang penjualan rempah-rempah kepada orang Eropa lainnya di bawah ancaman hukuman. ${ }^{8}$

7) Kesultanan Cirebon tidak dihancurkan oleh Mataram, namun secara perlahan kesultanan ini ditransformasikan dari kerajaan maritim menjadi negara feudal oleh Mataram. Lihat Singgih Tri Sulistiyono, "Perkembangan pelabuhan Cirebon dan pengaruhnya terhadap kehidupan sosial ekonomi masyarakat kota Cirebon 1859-1930” (Tesis Master, Universitas Gadjah Mada, Yogyakarta, 1994), hlm. 135-139. Lihat juga Sharon Siddique, "Relics of the Past? A Sociological Study of the Sultanates of Cirebon, West Java" (Disertasi Doktor, University of Bieleveld, 1977).

8) L. Nagtegaal, Riding the Dutch tiger: The Dutch East Indies Company and the Northeast Coast of Java 1680-1743 (Leiden: KITLV Press, 1996), hlm. 21. Penaklukan Makassar oleh VOC tahun 1667, misalnya, telah menyebabkan eksodus pedagang secara besar-besaran dari Sulawesi selatan ke pantai utara Jawa. 
Pada awalnya VOC memiliki rencana untuk memusatkan jaringan dagang mereka di Selat Malaka (yaitu di pelabuhan Malaka) dan Selat Sunda (yaitu Batavia). Namun demikian pada abad ke-17 rencana ini berubah. Sejak 1677 dan seterusnya, Belanda terlibat aktif dalam serangkaian sengketa suksesi dan perebutan kekuasaan di Jawa. Dengan memanfaatkan konflik yang ada, akhirnya Belanda dapat mengurangi kekuasaan raja-raja Mataram hingga dalam posisi yang bergantung kepada Belanda. Mulai akhir abad ke-18, hingga taraf tertentu kerajaan Mataram, Banten, dan Cirebon sudah menjadi semacan vasal VOC. Selain itu, mereka juga menguasai ekonomi daerah-daerah yang paling produktif di Jawa melalui pungutan pajak dan berbagai jenis upeti. VOC mulai memperkenalkan tanaman-tanaman baru utnuk dibudidayakan di Jawa yang memiliki jumlah penduduk yang signifikan yang berada di bawah kekuasaan pemimpin pribumi yang relatif sudah bisa dikendalikan Belanda. Dengan demikian, VOC secara bertahap menjadikan Jawa sebagai basis kekuasaannya. Sementara itu cengkeraman kekuasaan maritim mereka di luar Jawa mulai menurun. ${ }^{9}$

Jatuhnya pusat-pusat perdagangan pribumi di Nusantara telah memaksa pedagang pribumi menyesuaikan diri dengan situasi baru. Hal ini terjadi setidaknya di sebagian besar kota-kota pelabuhan di pantai utara Jawa. Dalam hal ini telah terjadi proses feodalisasi dalam masyarakat Jawa karena runtuhnya kegiatan perdagangan mereka (Sulistiyono \& Rochwulaningsih, 2013: 115-127). Sementara itu, beberapa pedagang pribumi menggeser profesi mereka menjadi bajak laut. Ada paralel antara dominasi VOC di laut dan perkembangan bajak laut di perairan Nusantara. Tentu saja, pembajakan terjadi di sepanjang rute perdagangan yang sibuk. Target bajak laut tidak hanya kapal asing, tetapi juga pedagang pribumi. Kadang-kadang mereka merampok desa-desa pesisir, menangkap penduduk desa dan menjual mereka sebagai budak (Reid, 1983; Lapian, 1987). Namun demikian, para pedagang pribumi masih ada dan terus melakukan kegiatan pelayaran dan perdagangan seperti yang mereka lakukan sebelum kehadiran orang Barat. Bahkan, ada kecenderungan baru di mana pelayaran prahu berfungsi hanya sebagai layanan tambahan dari pelayaran Belanda. Mereka bertindak sebagai distributor barang impor dari pelabuhan-pelabuhan besar ke pelabuhan-pelabuhan kecil, dan sebaliknya mereka mengangkut produk yang diekspor dari kecil ke pelabuhan besar yang akan dikirim ke luar negeri

9) C.D. Cowan, "Continuity and change in the international history of maritime South East Asia”, Journal of Southeast Asian History 9 (1968) (1), hlm. 10. Gaastra \& Bruijn juga menyatakan bahwa abad ke-17 dan 18 menyaksikan VOC mentransformasikan dirinya sebaai kekuatan teritorial; Lihat F.S. Gaastra \& J.R. Bruijn, "The Dutch East India Company's shipping, 1602-1795, in a comparative perspective”, dalam: J.R. Bruijn \& F.S. Gaastra (eds), Ships, sailors and spices: East India Companies and their shipping in the 16th, 17th and 18th centuries (Amsterdam: NEHA, 1993), hlm. 178. Lihat juga F.S. Gaastra, De geschiedenis van de VOC (Zutphen: Walburg, 2002), hlm. 57-65. 
(Sulistiyono, 2003). Kebijakan kontrol yang ketat dan penguasaan modal telah memungkinkan Belanda mendominasi pelayaran dan perdagangan di kepulauan Indonesia. Dengan demikian, 'takdir' sebagai bangsa maritim telah diputus oleh kekuatan kolonialisme.

\section{Paradigma Maritim dalam Membangun Indonesia}

Uraian mengenai sejarah perkembangan kerajaan Sriwijaya dan Majapahit tersebut di atas sebetulnya cukup memberikan pelajaran kita untuk melakukan revitalisasi dan sekaligus reinterpretasi terhadap paradigma maritim. Dalam hal ini pembangunan negara maritim tidak dapat dilakukan secara parsial tetapi harus didasari pada paradigma maritim sesuai dengan jati diri yang dapat dilihat dari perjalanan sejarah bangsa itu sendiri. Paradigma maritim paling tidak mencakup aspek politik, ekonomi, dan budaya.

\section{Paradigma Maritim di Bidang Politik}

Bagi sebuah negara maritim, paradigma maritim di bidang politik merupakan hal yang sangat penting karena hal ini akan menentukan bagaimana sumberdaya yang ada baik sumberdaya alam (laut dan darat), sumber daya manusia, sumber daya budaya, sumber daya teknologi, dan sebagainya dikelola secara optimal sesuai dengan potensi dan jatidirinya. Tanpa paradigma yang jelas, pengelolaan segala macam sumber daya yang ada akan menjadi tidak terarah. Jika ini terjadi, upaya membangun negara maritim yang jaya tidak akan tercapai dan akan gagal di tengah jalan.

Paradigma maritim di bidang politik paling tidak mencakup landasan ideologi, sistem pemerintahan dan pertahanan dan keamanan. Negara maritim Indonesia yang berjaya di masa yang akan datang memerlukan landasan ideologis yang jelas. Dalam hubungan ini, sesuai dengan komitmen para founding fathers yang meletakkan Pancasila sebagai ideologi bangsa Indonesia masih dan akan tetap relevan di masa yang akan datang. Di samping Pancasila secara ideal mampu merangkai semua aspek kehidupan, baik kehidupan pribadi, kemasyarakatan, maupun kebangsaan yang mencakup sistem kepercayaan, kemanusiaan, kebangsaan, sistem demokrasi dalam pemerintahan, maupun aspek keadilan sosial dalam kehidupan bersama. Semua aspek itu sangat diperlukan dalam membangun kehidupan bersama sebagai komunitas bangsa.

Aspek yang juga sangat fondamental dari ideologi Pancasila adalah semangat untuk menerima perbedaan sebagai modal dasar untuk membangun persatuan, yaitu dengan semboyan Bhinneka Tunggal Ika yang maknanya adalah berbeda-beda tetapi tetap satu. Konsep ini mirip dengan multikulturalisme dalam zaman modern sekarang. Oleh karena latar belakang perkembangan historis yang berbeda-beda antara satu kelompok sosial dengan kompok sosial yang lain di Indonesia, maka mereka juga 
memiliki tingkat multikulturalitas yang berbeda-beda. Hal itu ditentukan baik oleh karakteristik kondisi alamiah maupun aspek-aspek lain yang terkait seperti ekonomi, politik, sosial, budaya, dan sebagainya. Jadi pluralitas masyarakat Indonesia ditentukan baik oleh kondisi geografis Indonesia yang sangat luas, ras, dan kelompok etnik yang sangat beragam, serta sejarah yang berbeda-beda. Pluralitas yang sangat complicated itu masih dipertajam dengan perbedaan status dan tingkat ekonomi. Dalam hubungan itulah semangat dan perspektif multikulturalisme (bukan sekedar pluralisme) perlu dikembangkan dalam memperkokoh salah satu pilar kebangsaan Indonesia, yaitu bhinneka tunggal ika.

Semboyan dan semangat ini sangat penting untuk disosialisasikan dan diinternalisasikan ke dalam kepribadian masyarakat indonesia. Hal ini bukan merupakan sesuatu yang aneh mengingat secara sosiologis dan kultural, masyarakat Indonesia merupakan masyarakat plural yang memiliki potensi yang sangat besar bagi munculnya konflik dan perpecahan jika tidak disemangati oleh bhinneka tunggal ika atau semangat multikulturalistik. ${ }^{10}$ Meskipun masyarakat Indonesia merupakan masyarakat yang pluralistik dari sisi ras, etnik, status, kepercayaan, dan sebagainya, namun merupakan suatu kesatuan guna mencapai tujuan bersama dalam konteks NKRI (Negara Kesatuan Republik Indonesia) yang berdasarkan Pancasila dan UUD 1945. Namun demikian 'semangat bhinneka tunggal ika' ini bisa merupakan state of the art dan sebuah imagined condition. Sebagai state of the art konsep ini mengaju kepada kondisi riil di dalam masyarakat Indonesia yang pluralistik dan masih jauh dari keyakinan bhinekaan tunggal ika terbukti dengan masih maraknya kekerasan antarelemen di dalam masyarakat. Sebagai imagined condition, 'bhinneka tunggal ika-isme' merupakan sebuah cita-cita yang diidealisasikan yang tentu saja membutuhkan proses panjang untuk secara terus-menerus perlu perbaikan yang berkesinambungan (continual improvement) (Sulistiyono, 2011). Dengan demikian jika konsep pluralisme lebih mengacu kepada kondisi state of the art sedangkan kebhinnekaan tunggal ika atau multikulturalisme lebih mengacu kepada perspektif dan semangat untuk mewujudkan imagined condition.

Terkait erat dengan aspek ideologi, cara pandang atau wawasan terhadap diri dan lingkungannya sebagai negara maritim juga sangat penting. Dalam hal ini pemerintah Indonesia sudah berusaha untuk merumuskan wawasan kemaritiman. Wawasan kemaritiman diawali dengan Deklarasi Djoeanda 13 Desember 1957, yang kemudian ditindaklanjuti dengan adanya konsep wawasan nusantara (Sulistiyono, 2009). Dalam Deklarasi Djoeanda dirumuskan:

10) Pada masa Indonesia modern, ada sekitar 200 rumpun bahasa Austronesia, dan lebih dari 150 keluarga bahasa Papua (Melanesia). Lihat Robert Cribb, Historical Atlas of Indonesia (Curzon: Richmond, Surrey, 2000). 


\begin{abstract}
"Segala perairan di sekitar, di antara dan yang menghubungkan pulau-pulau yang termasuk dalam daratan Republik Indonesia, dengan tidak memandang luas dan lebarnya, adalah bagian yang wajar dari wilayah daratan Negara Republik Indonesia dan dengan demikian merupakan bagian daripada perairan pedalaman atau perairan nasional yang berada di bawah kedaulatan Negara Republik Indonesia. Penentuan batas laut 12 mil yang diukur dari garis- garis yang menghubungkan titik terluar pada pulau-pulau Negara Republik Indonesia akan ditentukan dengan Undang-Undang” (Danusaputro, 1979: 1435). ${ }^{11}$
\end{abstract}

Sementara itu wawasan nusantara didefinisikan sebagai cara pandang dan sikap bangsa Indonesia mengenai diri dan bentuk geografinya berdasarkan Pancasila dan UUD 1945. Dalam pelaksanannya, wawasan nusantara mengutamakan kesatuan wilayah dan menghargai kebhinekaan untuk mencapai tujuan nasional. Dengan kata lain, wawasan nusantara merupakan cara pandang dan sikap bangsa Indonesia mengenai diri sendiri dan lingkungannya yang serba beragam dan bernilai strategis dengan mengutamakan persatuan dan kesatuan bangsa serta kesatuan wilayah dalam menyelenggarakan kehidupan masyarakat, berbangsa dan bernegara, untuk mencapai tujuan nasional (Suradinata, 2005: 12-14).

Jika dicermati secara detail, rumusan-rumusan baik yang ada di dalam Deklarasi Djoeanda maupun dalam Wawasan Nusantara ternyata serasa kurang "menggigit". Artinya tekanan visi kelautan belum begitu terasa. Dalam Deklarasi Djoeanda disebutkan:

"Segala perairan di sekitar, di antara dan yang menghubungkan pulau-pulau yang termasuk dalam daratan Republik Indonesia, dengan tidak memandang luas dan lebarnya, adalah bagian yang wajar dari wilayah daratan Negara Republik Indonesia...”.

Dari rumusan itu jelas kelihatan bahwa paradigma negara daratan atau negara kontinental masih kuat jika dibandingkan dengan paradigma negara maritim. Di situ tertulis dengan jelas bahwa laut-laut yang dimiliki oleh NKRI masih dipandang sebagai 'bagian yang wajar dari wilayah daratan Negara Republik Indonesia”. Hal ini tidak mengherankan karena pada waktu itu konsep 'archipelagic state' diterjemahkan dengan 'negara kepulauan', yang berarti negara yang memiliki wilayah yang terdiri dari banyak pulau yang ditengah-tengahnya adalah wilayah laut. Dengan demikian jelas kelihatan bahwa eksistensi laut-laut yang ada hanya dipandang sebagai suplemen dari wilayah darat.

11) Untuk teks lengkap Deklarasi dapat dilihat pada Munadjat Danusaputro, Wawasan Nusantara (dalam Ilmu, Politik \& Hukum) (Bandung: Alumni, 1979), hlm. 143-145. 
Kemajuan yang sedikit berarti telah dicapai dengan dirumuskannya wawasan nusantara yang tercakup dalam Ketetapan MPR Nomor IV/ MPR/1973 tanggal 22 maret 1973, TAP MPR Nomor IV/MPR/1978 tanggal 22 maret 1978 tentang GBHN, dan TAP MPR nomor II/MPR/1983 tanggal 12 Maret 1983. Dalam konteks itu wilayah daratan dan wilayah lautan merupakan satu kesatuan yang tidak dapat dipisahkan. Dengan demikian ada cara pandang yang seimbang dalam melihat wilayah daratan dan lautan.

Untuk membangun Indonesia ke depan sebagai negara maritim yang kuat diperlukan paradigma maritim yang kuat. Dalam hal ini konsep 'archipelagic state' tidak perlu diterjemahkan sebagai negara kepulauan dengan pengertian sebagaimana yang telah dijelaskan sebelumnya, tetapi harus diterjemahkan sebagai negara laut, yaitu negara yang wilayah utamanya terdiri dari laut yang di dalamnya terdapat pulau-pulau. ${ }^{12}$ Dengan demikian wilayah laut Indonesia bukan merupakan bagian dari wilayah daratan sebagaimana yang termaktub dalam Deklarasi Djoeanda. Wawasan Nusantara yang memandang lautan dan daratan sebagai kesatuan yang seimbang juga masih kurang tegas. Cara pandang itu harus diputar 180 derajad, bahwa wilayah daratan (kepulauan) hanya merupakan bagian dari wilayah laut dari negara maritim Indonesia. Dalam konteks ini, pembangunan wilayah daratan (pulau-pulau) hanyalah merupakan sebagian kecil saja pambangunan wilayah negara maritim Republik Indonesia karena sekitar 80 persen lebih wilayah Indonesia berupa laut.

Paradigma maritim atau mungkin bisa disebut juga sebagai visi kemaritiman atau kelautan sebagaimana yang digambarkan di atas akan mempengaruhi cara mendefinisikan negara Indonesia sebagai negara maritim. Selama ini banyak orang yang berpikiran dikotomis yang mempertentangkan aspek daratan dan lautan. Padahal sesungguhnya membangun Indonesia seharusnya berarti membangun sektor kemaritiman. Membangun daratan di pulau-pulau dengan sendirinya merupakan bagian kecil dari pembangunan negara maritim Indonesia. Dengan demikian perlu cara berpikir yang integratif yang mensinergikan antara aspek kelautan dan pulau sebagaimana yang pernah dilakukan oleh negara-negara maritim besar dalam sejarah Indonesia. Dalam hubungan ini, definisi

12) Hal ini sesuai dengan pendapat Lapian yang menyatakan bahwa antara konsep kepulauan dan archipelago memiliki perbedaan yang fundamental. Istilah archipelago berasal dari bahasa Italia pada masa Abad Pertengahan, archipelagos, yang berasal dari kata archi, yang berati paling utama dan pelagus yang berarti laut. Dengan demikian makna archipelago bukanlah merupakan 'sekumpulan pulau' atau 'a group of islands' tetapi 'hamparan perairan laut yang di dalamnya terdapat pulau-pulau' atau 'a body of water containing islands'. Dengan demikian menurut Lapian konsep negara kepulauan untuk Indonesia harus mengacu kepada makna yang ke duayaitu Indonesia sebagai negara laut atau negara maritim, bukan sebagai negara kepulauan dalam pengertian sebagai 'islands state'. Lihat A.B. Lapian, 'Laut, pasar, dan komunikasi antar-budaya', paper dipresentasikan pada Kongres Sejarah Nasional 1996 (Jakarta: 1996), hlm. 1. 
negara maritim yang cocok untuk Indonesia adalah sebuah negara yang mampu membangun kekuatan maritimnya (seapowers) baik di bidang pelayaran dan perdagangan (mechant shipping), kekuatan pertahanan dan keamanan maritim (maritime figting instruments), dan kemajuan teknologi kemaritiman (maritime technology) untuk dapat memanfaatkan potensi yang dimilikinya secara sinergis (laut dan darat) dalam kerangka dinamika geopolitik guna mencapai kemakmuran dan kejayaan bangsa dan negaranya. Dengan kekuatan maritim (maritime powers) itu negara maritim Indonesia akan mampu mendayagunakan secara optimal baik potensi yang dimilikinya sendiri, yaitu potensi sumber daya alamiah (natural resources) baik yang berupa pulau maupun laut, sumber daya manusia (human resources), sumber daya pemerintahan (political resources), dan sumber daya budaya (cultural resources), maupun potensi yang lahir dari lingkungan geopolitik strategis yaitu dengan memanfaatkan lingkungan strategis guna mencapai kejayaan bangsa dan negara.

Dalam hal ini perlu diingat kembali sebagai negara maritim, wilayah NKRI sebagai wadah sekaligus isi berupa lautan yang di dalamnya ada pulaupulau. Sebagaimana kerajaan-kejayaan maritim besar di Nusantara, mereka memproduksi berbagai komoditi di pulau-pulau terutama ditujukan untuk kepentingan perdagangan maritim internasional, di samping tentu saja untuk memenuhi kebutuhan sendiri.

Paradigma maritim sebagaimana yang diuraiakan di atas harus diterjemahkan dan diejawantahkan dalam bidang politik, hukum, pemerintahan, dan sistem pertahanan dan keamanan. Dengan kata lain sistem politik, hukum, pemerintahan, dan pertahanan serta keamanan nasional harus diorientasikan kepada pembangunan Indonesia sebagai negara laut.

\section{Paradigma Maritim di Bidang Ekonomi}

Paradigma maritim dalam pembangunan ekonomi bagi negara maritim Indonesia di masa yang akan datang juga merupakan persoalan yang paling krusial. Pembangunan ekonomi Indonesia tanpa dilandasi dengan paradigma maritim yang kuat tidak akan bisa membuahkan sebuah negara maritim Indonesia yang jaya. Dalam hal ini pembangunan ekonomi negara maritim paling tidak mencakup tiga aspek yaitu aspek sistem ekonomi, produksi dan distribusi. Secara makro, sistem ekonomi Indonesia harus didasarkan atas ideologi ekonomi kerakyatan yang dapat digali dan dikembangkan dari ideologi Pancasila. Amandemen yang dilakukan terhadap Undangundang Dasar 1945, jika diperlukan, justru harus memperkuat implementasi ekonomi kerakyatan dalam kehidupan masyarakat. Bukan sebaliknya, selama periode reformasi ini justru amandemen terhadap UUD 1945 dan undang-undang yang diciptakan oleh pemerintah lebih mengarah kepada sistem ekonomi yang liberal. 
Sementara itu strategi dalam berproduksi sebagai elemen ekonomi yang paling penting perlu diupayakan adanya sinergitas antara potensi laut dan pulau. Untuk membangun masa depan Indonesia sebagai negara maritim, tidak bisa hanya membangun kemampuan berproduksi di bidang kelautan saja (marine-based production capacity) seperti perikanan, garam, tambang, dan sebagainya tetapi juga harus mampu membangkitkan kemampuan produksi di daratan (land-based production capacity). Pada prinsipnya, pemerintah harus mendorong semua elemen di dalam masyarakat untuk menciptakan produk-produk yang dibutuhkan oleh pasar yang memiliki keunggulan komparatif dan kompetitif (comparative and competitive advantages) tanpa mempersoalkan marine dan land-based sectors karena hakekatnya semuanya adalah pembangunan laut sesuai dengan visi negara maritim. Perlu ditekankan bahwa keberadaan pulau-pulau di Indonesia merupakan bagian dari kekayaan laut.

Dalam hal ini perlu ditekankan juga mengenai orientasi produksi. Dengan belajar dari sejarah maritim Nusantara dapat dipetik pelajaran bahwa penciptaan produksi dalam ekonomi tidak semata-mata ditujukan untuk memenuhi kebutuhan sendiri (self sufficient) tetapi juga untuk diperdagangkan dalam pasar internasional. Orientasi produksi untuk menciptakan surplus sangat penting dalam negara maritim. Surplus dalam perdagangan internasional dapat digunakan untuk mendukung kejayaan negara maritim. Dengan orientasi seperti ini, mereka tidak hanya makmur karena dapat mencukupi kebutuhan sendiri, tetapi juga mampu memanfaatkan surplus produksi untuk kepentingan kejayaan negara.

Armada transportasi laut (merchant shipping fleet) merupakan salah satu faktor terpenting untuk pembangunan ekonomi negara maritim yang maju. Kepemilikan armada kapal sendiri merupakan sesuatu yang sangat penting bagi negara maritim. Situasi yang menyedihkan sekarang ini sedang terjadi di Indonesia. Pada 2005 misalnya hanya sekitar 53 persen pelayaran domestik dan 3,4 persen pelayaran internasional yang masih berada di tangan perusahaan nasional Indonesia. Angka itu cenderung terus mengalami keterpurukan (Kamaluddin, 2005: 37). Sejauh makro ekonomi dipertimbangkan, perdagangan antarpulau dan internasional yang dilayani secara efisien oleh perusahaan pelayaran milik sendiri yang efisien akan mencegah terjadinya pengaliran devisa keluar negeri. Sementara itu, adalah sangat penting bagi negara maritim untuk memiliki angkatan laut dan patroli polisi (maritime fighting instruments) yang kuat untuk mengamankan wilayah laut dari semua jenis tindakan kriminal dan ekspansi politik dan militer dari negara asing. Kewibawaan sebuah negara maritim bergantung kepada hal tersebut. Kapal-kapal patroli yang tidak mampu mengejar kapalkapal pencuri ikan adalah suatu bentuk pelecehan terhadap kewibawaan sebuah negara maritim. 
Aspek fundamental lain dari pembangunan ekonomi negara maritim Indonesia adalah masalah integrasi ekonomi nasional. Disparitas ekonomi di antara pulau-pulau dan/ atau daerah masih terlihat dengan jelas sepanjang sejarah Indonesia. Ada beberapa pulau yang telah berkembang secara ekonomi, tetapi masih banyak juga pulau-pulau dan/atau daerah yang masih belum berkembang (Kamaluddin, 2005: 82-3). Di samping itu, masih terdapat berbagai persoalan yang berkaitan dengan hubungan dan ketergantungan di antara pulau-pulau itu. Padahal, penciptaan ketergantungan di antara pulaupulau yang ada akan memiliki andil yang besar dalam penguatan integrasi ekonomi nasional yang pada gilirannya juga akan memperkuat integrasi budaya dan politik (Drake, 1989: 2-3).

Selain itu, Indonesia yang terdiri dari ribuan pulau dengan beragam potensi ekonomi dapat dijadikan sebagai modal dasar untuk menciptakan suatu tahap pembangunan ekonomi yang disebut sebagai complete economic integration. ${ }^{13}$ Dalam kerangka itu, berbagai wilayah Indonesia perlu direkayasa sedemikian rupa sehingga menjadi suatu area ekonomi yang mandiri yang relatif mampu memenuhi kebutuhan sendiri. Dalam situasi seperti itu internal supplay and demand akan dapat berkembang dengan baik dan masing-masing wilayah dikembangkan dengan cara tertentu sehingga mampu berperan dalam mekanisme pasar nasional yang mandiri. Hal ini perlu dilakukan dalam rangka menghidupkan perekonomian domestik yang akan mampu memberikan kontribusi terhadap GDP (Gross Domestic Product) yang akan memberikan kontribusi penting untuk membangun imunitas perekonomian Indonesia dari konjungtur dan krisis global. Jadi untuk selanjutnya export-led economy dikembangkan di atas kemandirian dan dalam kerangka memperkuat ekonomi nasional.

Dengan belajar dari krisis-krisis ekonomi yang diderita oleh Indonesia dan beberapa negara lain, dapat diperoleh palajaran bahwa sebuah negara yang terlalu menggantungkan PDB-nya dari sektor ekspor (seperti Singapura dan Korea Selatan) akan sangat rapuh terhadap krisis ekonomi global. Oleh karena itu penguatan ekonomi domestik termasuk kemandirian dalam memenuhi kebutuhan pokok merupakan langkah yang sangat penting bagi pembangunan ekonomi negara maritim Indonesia di masa yang akan

13) Biasanya konsep complete economic integration ini merupakan tahap akhir dari kerjasama blok ekonomi regional di antara beberapa negara sekawasan di mana negaranegara anggota tidak lagi mempersoalkan dan mengontrol kebijakan ekonomi negaranegara anggotanya mencakup penggabungan moneter secara total (full monetary union) dan harmonisasi kebijakan fiscal (complete fiscal policy). Tahap-tahap untuk mencapai complete economic integration adalah: preferential trading area, free trade area, customs union, common market, economic and monetary union, dan terakhir complete economic integration. Dalam hal ini complete economic integration biasanya hanya dijumpai dalam suatu negara, bukan kerjasama blok ekonomi regional dalam kerangka institusi supranasional. Lihat 'Economic Integration', dalam: http://en.wikipedia.org/wiki/ Economic_integration (Dikunjungi tanggal 30 Maret 2014). 
datang. Dalam hubungan ini, penelitian yang serius perlu dilakukan untuk memetakan kondisi dan dinamika pasar lokal dalam rangka menciptakan dan mengembangkan spesialisasi produksi dari pulau dan/ atau daerah sesuai dengan potensi mereka masing-masing. Hal ini akan memprekondisikan adanya arus supply and demand di antara pulau dan daerah sebagai sebuah sistem yang pada gilirannya akan mendorong perkembangan perdagangan ekspor dan impor.

\section{Paradigma Maritim dalam Pembangunan Sosial-Budaya}

Sangat penting untuk dicatat bahwa untuk membangun negara maritim yang besar tidak hanya cukup dengan melakukan eksploitas sumber daya kelautan saja. Pembangunan negara maritim mensyaratkan dilakukannya sosialisasi dan enkulturasi nilai-nilai sejarah dan budaya maritim melalui berbagai media, seperti pendidikan, seni, sastra, dan sebagainya. Tanpa landasan sosial budaya maritim, eksploitasi sumber daya kelautan akan berubah menjadi bencana sebagaimana yang sudah terjadi pada sektor daratan.

Indonesia sebetulnya memiliki potensi menjadi negara maritim yang besar. Alfred Thayer Mahan (1965) misalnya berpendapat bahwa ada enam syarat yang harus dimiliki untuk menjadi negara maritim yang besar, yaitu: posisi geografis, karakteristik daratan dan pantai, luas wilayah, jumlah penduduk, karakter penduduk, dan karakter pemerintahan. Di antara enam syarat tersebut barangkali tinggal syarat ke lima dan ke enam yang belum sepenuhnya dimiliki oleh Indonesia yaitu karakter penduduk dan karakter pemerintahan. Oleh sebab itu jika paradigma maritim tidak hanya perlu diterapkan dalam pembangunan politik dan ekonomi, tetapi juga dalam pembangunan sosial budaya bahari yang selama masa dominasi kolonial mengalami kemunduran. Oleh sebab itu perlu sosialisasi dan internalisasi nilai-nilai kebaharian dalam kehidupan sosial budaya masyarakat Indonesia.

Pembangunan sosial budaya maritim dapat dilakukan melalui pendidikan baik formal maupun non-formal yang merupakan media untuk sosialisasi dan internalisasi nilai-nilai sejarah dan budaya maritim. Selain itu peletakan landasan sosial budaya juga bisa dilakukan melalui revitalisasi dan penguatan lembaga-lembaga sosial yang telah mengakar di dalam masyarakat. Demikian juga, penciptaan lembaga modern yang memiliki fungsi sebagai think-thank bagi pengembangan negara maritim juga perlu dilakukan. Dengan demikian baik pemerintah maupun rakyat memiliki peran yang sama-sama penting dalam pembangunan sosial budaya bagi negara maritim yang besar di masa yang akan datang.

Dalam mensosialisasikan dan menginternalisasikan budaya maritim, peran pembelajaran sejarah maritim Indonesia di lembaga-lembaga pendidikan amat penting. Dalam konteks ini sejarah maritim Indonesia mampu memberikan eksplanasi mengenai komunikasi lintas budaya (cross- 
cultural communication) lewat media laut antara satu komunitas dengan komunitas yang lain yang menjadi dasar bagi proses formasi sebuah bangsa yang kemudian disebut sebagai bangsa Indonesia. Hal ini dimungkinkan karena hubungan lewat laut telah memprekondisikan terjadinya komunikasi lintas budaya baik lewat saluran pelayaran maupun perdagangan dan bahkan saluran politik dan militer. Kondisi geografis telah memungkinkan aktivitas ini bisa berlangsung dengan baik. Fernard Braudel mengatakan, bahwa laut mengandung dinamika yang menciptakan kesatuan, hubungan antarmanusia dan antar bangsa lewat transportasi, perdaÂgangan, dan pertemuan budaya (Braudel, 1976).

Pandangan Braudel tidak jauh berbeda dengan pandangan yang dianut negara Indonesia sebagai negara maritim. Dalam hal ini lautan bukan memisahkan, melainkan justru mempersatukan pulau-pulau. Adalah suatu kenyataan bahwa Indonesia merupakan satu kesatuan politik yang mengikat beribu-ribu pulau dan beratus-ratus suku bangsa. Hal itu menunjukkan adanya perkembangan dinamika faktor hubungan antar pulau, antar suku bangsa, dan antar bangsa yang telah memainkan peranan yang sangat penting dalam formasi bangsa Indonesia. Di sini laut dengan segala bentuk transportasinya merupakan sarana hubungan utama. Melalui hubungan laut ini para penguasa pribumi dari berbagai daerah di Indonesia mengadakan hubungan dengan pihak luar. Dari hubungan ini tercipta kegiatan-kegiatan pertukaran, perdagangan, dan perjumpaan budaya, yang kemudian menghasilkan peradaban yang semakin maju, budaya setempat yang semakin diperkaya. Perwujudan dari kemajuan budaya antara lain dapat dilihat dari tumbuhnya kota-kota pantai dengan pelabuhannya yang menjadi pusat dinamika perdagangan, pelayaran, dan teknologi perkapalan serta pusat kekuatan politik. Dengan demikian melalui pembelajaran sejarah maritim, wisdom akan bisa dipetik oleh para siswa mengenai nilainilai kebaharian yang memperkuat proses komunikasi lintas budaya yang sebetulnya menjadi fondamen yang kokoh untuk integrasi bangsa Indonesia di masa yang akan datang sebagai negara maritim.

\section{Catatan Akhir}

Dari uraian di atas dapat diambil beberapa catatan penting. Pertama, fakta geografis dan pengalaman historis telah menujukkan bahwa bangsa Indonesia di masa lampau telah telah berkembang menjadi bangsa maritim. Dominasi kolonialisme telah meredupkan kehidupan sebagai bangsa maritim tersebut. Oleh sebab itu tugas generasi sekarang dan yang akan datang adalah merevitalisasi segala aspek kehidupan bangsa dengan menerapkan paradigma maritim dalam pembangunan bangsa guna meraih kejayaan sebagai bangsa maritim yang besar di masa mendatang yang sesuai dengan jatidiri dan sejarah bangsa Indonesia. 
Kedua, pembangunan negara maritim tidak dapat dilakukan secara parsial. Untuk membangun sebuah negara maritim harus didasarkan pada paradigma maritim di bidang pembangunan politik, ekonomi, dan sosial budaya. Paradigma maritim di bidang pembangunan politik mencakup aspek ideologi, pemerintahan, pertahanan dan keamanan. Sementara itu pembangunan ekonomi maritim mencakup aspek sistem ekonomi, aspek produksi, dan distribusi. Pembangunan sosial budaya maritim paling tidak mencakup aspek pendidikan, kelembagaan, dan peran rakyat dalam pembangunan negara maritim.

Ketiga, untuk membangun Indonesia sebagai negara maritim yang kuat diperlukan paradigma maritim yang kuat pula, yaitu wawasan atau pola pikir yang memandang wilayah daratan (kepulauan) sebagai bagian dari wilayah laut dari negara maritim Indonesia.

Keempat, paradigma maritim atau kelautan sebagaimana yang digambarkan di atas akan mempengaruhi cara mendefinisikan negara Indonesia sebagai negara maritim. Definisi negara maritim yang cocok untuk Indonesia adalah sebuah negara yang mampu membangun kekuatan maritimnya (seapowers) baik di bidang pelayaran dan perdagangan (mechant shipping), kekuatan pertahanan dan keamanan maritim (maritime figting instruments), dan kemajuan teknologi kemaritiman (maritime technology) untuk dapat memanfaatkan potensi yang dimilikinya secara sinergis (laut dan darat) dalam kerangka dinamika geopolitik guna mencapai kemakmuran dan kejayaan bangsa dan negaranya.

Kelima, satu hal yang tidak akalah penting adalah bahwa untuk membangun negara maritim yang besar perlu sosialisasi dan enkulturasi nilai-nilai budaya sejarah dan budaya maritim melalui media pendidikan, seni, sastra, dan sebagainya. Hal ini terkait dengan kenyataan bahwa selama masa penjajahan jiwa dan semangat bahari telah mengalami penurunan.

\section{Referensi}

A.B. Lapian. 1984. "The Maritime Network in the Indonesian Archipelago in the Fourteenth Century" in SEAMEO Project in Archeology and Fine Arts SPAFA. Final Report: Consultative Workshop on Research on Maritime Shipping and Trade Networks in Southeast Asia. Cisarua, West Java, Indonesia: 20-27 November.

A.B. Lapian. 1987. Orang Laut-Bajak Laut-Raja Laut:Sejarah kawasan Laut Sulawesi abad XIX. Disertasi. Yogyakarta: Universitas Gadjah Mada.

A.B. Lapian. 1996. "Laut, Pasar, dan Komunikasi Antar-Budaya". Paper dipresentasikan pada Kongres Sejarah Nasional 1996. Jakarta.

Berg, C.C. 1951/52. "De Sadeng Oorlog en de Myth of Great Majapahit”. Indonesia 5.

Wilkinson, R.J. 1912. “The Malacca Sultanate”. JMBRAS 61.

Blagden, C.O. 1909. "Notes on Malay History”. JMBRAS 53. 
Braddel, R. 1936. "An Introduction to the Study of Ancient Times in the Malay Peninsula and the Straits of Malacca”. JMBRAS 14.

Braudel, Fernand. 1976. The Mediterranean and Mediterranean World in the Age of Philip II Vol. I (terjemahan S. Reynold). New York: Harper Colophon Book.

Broek, J.O.M. 1942. Economic Development of the Netherlands Indies. New York: Institute of Pacific Relations.

Burger, D.H. 1975. Sociologisch-Economische Geschiedenis van Indonesia I. Amsterdam: Royal Tropical Institute.

Colless, B.E. 1975. "Majapahit Revisited: External Evidence on the Geography and Ethnology of East Java in the Majapahit Period". JMBRAS 2.

Cribb, Robert. 2000. Historical Atlas of Indonesia. Singapore: Cuzon Press.

Christie, J.W. 1999. "Asia Sea Trade between the Tenth and Thirteenth Centuries and Its Impact on the States of Java and Bali” dalam H.P. Ray (ed.). Archeology of Seafaring: The India Ocean in the Ancient Period. Delhi: Pragati.

Coedes, G. 1968. The Indianised States of Southeast Asia. Kuala Lumpur: University of Malaya Press.

Cortesao, A. 1944. The Suma Oriental of Tome Pires: An Account of the East, from the Red Sea to Japan, Written in Malacca and India in 1512-1515. London: Hakluyt Society Series.

Cowan, C.D. 1968. "Continuity and Change in the International History of Maritime South East Asia”. Journal of Southeast Asian History 9.

Cribb, Robert. 2000. Historical Atlas of Indonesia. Curzon: Richmond, Surrey.

Curtin, Philip D. 1998. Cross-cultural Trade in World History. Cambridge: Cambridge University Press.

De Graaf, H.J. \& Th. Pigeaud. 1989. Kerajaan-kerajaan Islam di Indonesia. Jakarta: Grafiti Pers.

Drake, Christine. 1989. National Integration in Indonesia: Patterns and Policies. Honolulu: University of Hawaii Press.

Ermaya Suradinata. 2005. Hukum Dasar Geopolitik dan Geostrategi dalam Kerangka Keutuhan NKRI. Jakarta: Suara Bebas.

Gaastra, F.S. \& J.R. Bruijn. 1993. “The Dutch East India Company's shipping, 16021795, in a Comparative Perspective" dalam J.R. Bruijn \& F.S. Gaastra (eds). Ships, Sailors and Spices: East India Companies and their Shipping in the 16th, 17th, and 18th Centuries. Amsterdam: NEHA.

Gaastra, F.S. 2002. De Geschiedenis van de VOC. Zutphen: Walburg.

Hall, Kenneth R. 1985. Maritime Trade and State Development in Early Southeast Asia. Honolulu: University of Hawaii Press.

Laode M. Kamaluddin. 2005. Indonesia Sebagai Negara Maritim dari Sudut Pandang Ekonomi. Malang: Universitas Muhammadiyah Malang Press.

Mahan, Alfred Thayer. 1965. The Influence of Sea Power upon History 1660-1783. London: Methuen.

Manguin, Piere-Yves. 1993. "Palembang and Sriwijaya: An Early Malay HarbourCity Rediscovered”. JMBRAS 1 (66).

Manguin, Pierre-Yves. 1993. "The Vanishing jong: Insular Southeast Asian Fleet in Trade and War (Fifteenth to Seventeenth Centuries)" dalam Anthony Reid (ed.). Southeast Asia in the Early Modern Era: Trade, Power, and Belief. Itacha: Cornell University Press.

Pigeaud, Th. 1960-1963. Java in the Fourteenth Century: A Study in Cultural History 
$I V$. The Hague.

McRoberts, R.W.1986. "Notes on Events in Palembang 1389-1511: The Overlasting Colony”. JMBRAS 1.

Reid, Anthony (ed.). 1983. Slavery, Bondage and Dependency in Southeast Asia. St. Lucia: University of Queensland Press.

Munadjat Danusaputro. 1979. Wawasan Nusantara (dalam Ilmu, Politik \& Hukum). Bandung: Alumni.

Nagtegaal, L. 1996. Riding the Dutch Tiger: The Dutch East Indies Company and the Northeast Coast of Java 1680-1743. Leiden: KITLV Press.

Sartono Kartodirdjo, Marwati Djoened Poesponegoro, Nugroho Notosusanto. 1975. Sejarah Nasional Indonesia II. Jakarta: Balai Pustaka.

Siddique, Sharon. 1977. Relics of the Past? A Sociological Study of the Sultanates of Cirebon, West Java. Disertasi. University of Bieleveld.

Singgih Tri Sulistiyono. 1994. Perkembangan Pelabuhan Cirebon dan Pengaruhnya terhadap Kehidupan Sosial Ekonomi Masyarakat Kota Cirebon 1859-1930. Tesis. Yogyakarta: Universitas Gadjah Mada.

Singgih Tri Sulistiyono. 2003. The Java Sea Network: Patterns in the Development of

Interregional Shipping and Trade in the Process of National Economic Integration, 1870s-1970s. Ph.D. Dissertation. Leiden: Leiden University.

Singgih Tri Sulistiyono. 2009. "National Interest and International Pressure: Decolonization on the Law of The Sea in the Post-Independence Indonesia". makalah dipresentasikan pada the ENCOMPSS Conference 'States of Transition: Modernization, Performance and Meaning of State and Authority in the Era of Decolonization. Medan, Indonesia: 6-8 January.

Singgih Tri Sulistiyono. 2011. "Multikulturalisme dalam Perspektif Budaya Pesisir", makalah dipresentasikan pada Seminar Nasional Multikulturalisme dan Integrasi Bangsa dalam Pembangunan Kebudayaan dan Pariwisata yang diselenggarakan oleh Kementerian Kebudayaan dan Pariwisata. Semarang: 7 Juli.

Singgih Tri Sulistiyono \& Yety Rochwulaningsih. 2013. "Contest for Hegemony: The Dynamics of Inland and Maritime Cultures Relations in the History of Java Island, Indonesia”. Journal of Marine and Island Cultures 2.

Soarez, Thomas. 1999. Early Mapping of Southeast Asia. Singapore: Periplus.

Soeroto. 1976. Sriwijaya Menguasai Lautan. Bandung, Jakarta: Sanggabuwana.

T.H. Purwaka. 1989. Indonesian interisland shipping: An assessment of the relationship of government policies and quality of shipping service. Ph.D. Dissertation. Hawaii: University of Hawaii.

Wales, H.G. Quaritch. 1978. "The Extent of Srivijaya's Influence Abroad”. JMBRAS $1(51)$.

Wolters, O.W. 1967. Early Indonesian Commerce: A Study of the Origins of Sri Vijaya. Itacha: Cornell University Press.

Wolters, O. W. 1979. "Studying Srivijaya”. JMBRAS 2. 